\title{
The adjustment of diet and insulin dose during long-term endurance exercise in Type 1 (insulin-dependent) diabetic men
}

\author{
T.Sane, E. Helve, R. Pelkonen and V.A. Koivisto \\ III Department of Medicine, Helsinki University Hospital, Finland
}

Summary. We examined in 2 consecutive years the effect of a $75-\mathrm{km}(>7 \mathrm{~h})$ cross country skiing on dietary and insulin requirements and glycaemic control in 9 Type 1 (insulin-dependent) diabetic patients. In the first year, the patients were hyperglycaemic $(20.9 \pm 1.8 \mathrm{mmol} / \mathrm{l})$ before the race due to excessive carbohydrate loading $(65 \mathrm{~g})$ and reduction (by $58 \%$ ) of short-acting insulin for breakfast. In the second year, breakfast included less carbohydrate $(40 \mathrm{~g})$ and more protein, and the morning short-acting insulin was reduced by $35 \%$. With this adjustment of therapy the pre-exercise hyperglycaemia was less $(p<0.05)$. The morning intermediate-acting insulin was reduced by 28 and $38 \%$ in consecutive years. During both races carbohydrate intake approximated $40 \mathrm{~g} / \mathrm{h}$, and blood glucose was maintained at near normal levels after $33 \mathrm{~km}$ of skiing. Hypoglycaemia did not occur during exercise, but one patient had symptomatic hypoglycaemia after finishing the second race. The day after exercise insulin sensitivity was increased in all four patients studied. Insulin treated patients can perform strenuous long-term exercise and maintain near normoglycaemia with a proper adjustment of therapy. Augmented insulin sensitivity may contribute to post-exercise hypoglycaemia.

Key words: Type 1 (insulin-dependent) diabetes, exercise, insulin dose, diet, insulin sensitivity.
In recent years there has been a burgeoning popularity of endurance exercise. This is reflected by a boom in events such as marathons and cross country ski races, with more than 10,000 participants in some of these competitions. These exertions cause probably the greatest demands for fuel metabolism with which man voluntarily taxes his metabolic system [1]. The events are also participated by insulin dependent diabetic patients, who may be in danger of either hypo- or hyperglycaemia during exercise, if the therapy is not modified accordingly. Although exercise has traditionally [2] been recommended for diabetic patients as an important part of therapy, more critical opinions have been expressed [3]; and we are not aware of any data regarding the proper adjustment of diet and insulin dose during long-term endurance exercise. Consequently, we planned the present study to gather information for the optimal adjustment of the therapy during longterm competitive exercise in insulin treated diabetic patients.

\section{Subjects and methods}

\section{Subjects}

We studied nine male Type 1 (insulin-dependent) diabetic patients, with mean (SEM) age $40.8 \pm 2.0$ years, weight $74 \pm 1 \mathrm{~kg}$ and height
$178 \pm 2 \mathrm{~cm}$ (Table 1). The duration of diabetes was $8 \pm 2$ years. Seven patients participated in the study in 1986, eight in 1987, and six on both occasions. Six patients used the combination of short- and in termediate-acting insulins, whereas three patients were on intermediate-acting insulin alone. The number of injections varied from one to four per day. The mean daily insulin dose was $37 \mathrm{U}$ (range 26-49 $\mathrm{U}$ ) and $33 U$ (range $14-43 U$ ) in 1986 and 1987 respectively. The mean $\mathrm{HbA}_{1}$ on the two occasions was $9.1 \pm 0.3 \%$ and $8.3 \pm 0.4 \%$ (normal range $6-9 \%$ ) respectively. Residual C-peptide activity was observed in four patients (Table 1). One patient had suffered myocardial infarction 2 years earlier, but the others had no clinically significant micro- or macrovascular complications.

The control group consisted of 17 healthy age and weight matched men. Of them, 10 participated in the study in 1986, 10 in 1987 , and three on both occasions. The data from the 17 control subjects are combined in the results.

All subjects had participated in the race earlier; they had 400-600 kilometers of ski-training during the preceding season, and each of them had registered for the race before they were invited to participate in the study. The nature and possible risks of the study were explained to the participants, and the study protocol was approved by the Ethical Committee of the Helsinki University Hospital.

\section{Exercise}

"Finlandia" cross-country ski race is an annual international competitive event with more than 10,000 participants each year. The race is arranged in southern Finland in late February. The distance of the track is $75 \mathrm{~km}$ in a hilly terrain. The race starts at 08.30 hours, and the skiing time varies from $4 \mathrm{~h}$ to $12 \mathrm{~h}$ depending on the fitness of the participant. The estimated energy consumption during the race is 
Table 1. Clinical data and individual adjustment of insulin dose in diabetic patients

\begin{tabular}{|c|c|c|c|c|c|c|c|c|c|c|c|c|c|c|}
\hline \multirow{3}{*}{$\begin{array}{l}\text { Patient } \\
\text { no. }\end{array}$} & \multirow{3}{*}{$\begin{array}{l}\text { Duration of } \\
\text { diabetes } \\
\text { (years) }\end{array}$} & \multirow{3}{*}{$\begin{array}{l}\text { C-peptide }{ }^{a} \\
(\mu \mathrm{g} / 1)\end{array}$} & \multicolumn{2}{|c|}{$\mathrm{HbA}_{1}(\%)$} & \multicolumn{8}{|c|}{ Morning insulin dose $(\mathrm{U})$} & \multicolumn{2}{|c|}{ Pre-lunch insulin dose $(\mathrm{U})^{\mathrm{b}}$} \\
\hline & & & \multirow{2}{*}{1986} & \multirow{2}{*}{1987} & \multicolumn{2}{|c|}{ Normal } & \multicolumn{2}{|c|}{ Skiing } & \multicolumn{2}{|c|}{ Normal } & \multicolumn{2}{|c|}{ Skiing } & 1986 & 1987 \\
\hline & & & & & $\mathrm{S}$ & I & $\mathrm{S}$ & I & $\mathrm{S}$ & I & $\mathrm{S}$ & $\mathrm{I}$ & $\mathrm{S}$ & $S$ \\
\hline 1 & 6 & 1.08 & 8.2 & 10.3 & - & 26 & - & 15 & - & 24 & 2 & 15 & - & - \\
\hline 2 & 3 & 0.14 & 11.2 & 7.6 & - & 24 & - & 22 & 3 & 22 & 2 & 16 & - & - \\
\hline 5 & 17 & 0.17 & 9.1 & 10.2 & 4 & 36 & - & 30 & 10 & - & 5 & 5 & - & 8 \\
\hline 6 & 3 & 0.54 & 9.2 & 7.9 & 7 & 30 & 3 & 22 & 10 & - & 5 & 5 & - & 8 \\
\hline 7 & 7 & 0.22 & 8.8 & - & 6 & 12 & 4 & 8 & - & - & - & - & - & - \\
\hline 8 & 8 & 0.50 & - & 8.7 & - & - & - & - & - & 28 & - & 21 & - & - \\
\hline 9 & 3 & - & - & 8.3 & - & - & - & - & - & 14 & - & 8 & - & - \\
\hline
\end{tabular}

${ }^{a}$ C-peptide values were measured after breakfast; ${ }^{b}$ normal day. $\mathrm{S}=$ short-acting insulin; $\mathrm{I}=$ intermediate-acting insulin

$4000 \mathrm{kcal}$. During the race, the skiers have access to fluid and food in nine service stations located at 8 - to $10-\mathrm{km}$ intervals. The temperature during the race in 1986 and 1987 ranged from $-18^{\circ} \mathrm{C}$ to $-25^{\circ} \mathrm{C}$ and from $-1{ }^{\circ} \mathrm{C}$ to $-5^{\circ} \mathrm{C}$ respectively.

\section{Patient instructions}

During the first study in 1986, the patients adjusted their food intake and insulin dose according to their previous experience with no specific advice from the investigators. Based on the results in the first study, specific instructions were given in 1987. The patients were advised to eat $40 \mathrm{~g}$ carbohydrate and $35 \mathrm{~g}$ protein for breakfast and approximately $40 \mathrm{~g} / \mathrm{h}$ carbohydrate during the exercise. The insulin regimen was planned individually with the aim to provide enough insulin to prevent post-breakfast hyperglycaemia, but to avoid high plasma insulin levels during the exercise.

\section{Measurements}

A venous blood sample for the determination of blood glucose [4] and plasma free insulin [5] was taken before the race ( $1 \mathrm{~h}$ after breakfast) and after $10 \mathrm{~km}$ (only in 1987), $33 \mathrm{~km}$ into the race and immediately after the end of the race. Serum creatinine kinase activity [6] and testosterone levels [7] were determined before and after the race. Glycosylated haemoglobin $\left(\mathrm{HbA}_{1}\right)$ (normal range 6.0 9.0\%) was measured by a microcolumn chromatography [8] (Isolab, Inc., Akron, Ohio, USA). Serum C-peptide was measured according to $\mathrm{Ku}$ zya et al. [5] using a commercial kit (Byk Mallincrodt, Dietzenbach, FRG). In 1987, seven diabetic patients were admitted to the hospital for the determination of nocturnal blood glucose profile at 4-h intervals. Body sensitivity to insulin was determined after an overnight $(10 \mathrm{~h})$ fast $[9,10] 2$ weeks before and in the morning after the race in two patients both in 1986 and 1987. No training had been done within $24 \mathrm{~h}$ before the first clamp study. The steady state mean plasma glucose $(4.8 \pm 0.1 \mathrm{mmol} / 1$ vs $4.9 \pm 0.1 \mathrm{mmol} / \mathrm{l})$ and insulin levels ( $53 \pm 4 \mathrm{mU} / 1$ vs $48 \pm 4 \mathrm{mU} / 1$ ) during the clamp study were comparable in studies before and after the race respectively. They were not significantly different from those in sedentary patients (glucose $4.8 \pm 0.1 \mathrm{mmol} / 1$, insulin $69 \pm 6 \mathrm{mU} / 1$ ), but the insulin level was lower than in healthy control subjects (glucose $5.1 \pm 0.2 \mathrm{mmol} / \mathrm{l}$, insulin $90 \pm 4 \mathrm{mU} / 1, p<0.001)$. The clamp data on matched sedentary diabetic patients and healthy control subjects are based on previous studies in our laboratory [10]. In each subject, the food and fluid intake was recorded before and immediately after the end of the competition.

\section{Statistical analysis}

Paired or unpaired Student's t-tests, where applicable, were used for the statistical analysis. The results are given as mean \pm SEM.

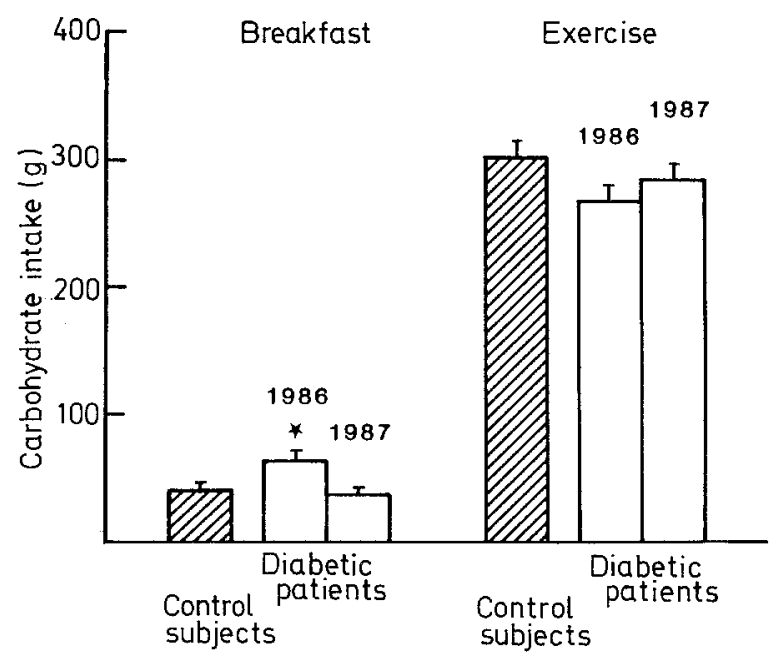

Fig. 1. Total carbohydrate intake at breakfast and during the $75-\mathrm{km}$ cross country ski race in control subjects and diabetic patients. In 1986, the patients ate more carbohydrate for breakfast than the control subjects or the patients 1 year later $*(p<0.05)$

\section{Results}

\section{Exercise intensity}

The mean duration of the exercise was comparable on the two occasions and was as long in the diabetic patients ( $7 \mathrm{~h}, 30 \mathrm{~min}$ and $7 \mathrm{~h}, 24 \mathrm{~min})$ as in the healthy control subjects $(7 \mathrm{~h}, 22 \mathrm{~min}$ and $7 \mathrm{~h}, 7 \mathrm{~min})$. As determined in the first study, the vigorousness of the exercise is reflected by a 4-5-fold rise in serum creatine kinase activity in diabetic patients (from $178 \pm 43 \mathrm{U} / 1$ to $708 \pm 138 \mathrm{u} / 1, p<0.001)$ and in the control subjects (from $154 \pm 31 \mathrm{U} / 1$ to $728 \pm 203 \mathrm{U} / 1, p<0.001$ ). Serum testosterone levels fell by $50 \%$ in the diabetic patients (from $22.8 \pm 2.0 \mathrm{nmol} / 1$ to $11.5 \pm 1.6 \mathrm{nmol} / 1, p<0.01$ ) and by $30 \%$ in the healthy control subjects (from $22.3 \pm 2.9 \mathrm{nmol} / 1$ to $15.6 \pm 2.7 \mathrm{nmol} / 1, p<0.05$ ).

\section{Food intake}

In 1986 , the patients ate for breakfast $65 \pm 5 \mathrm{~g}$ carbohydrate, which was $37 \%$ more than in the control subjects 


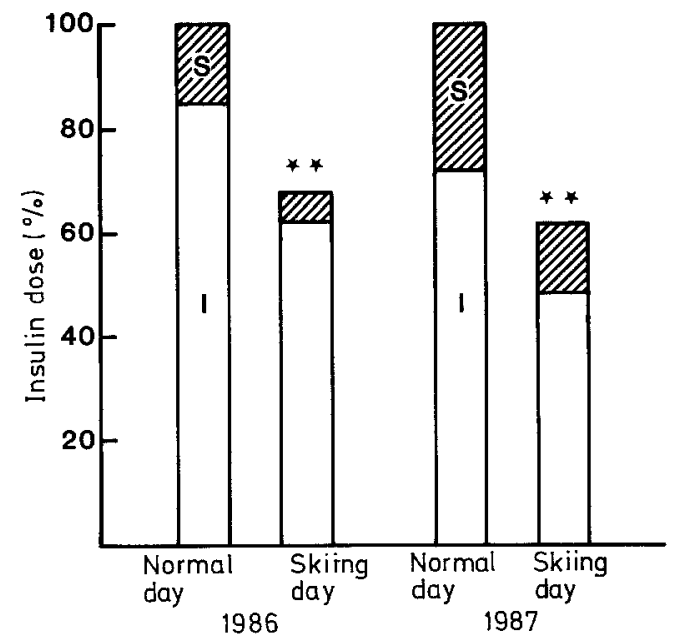

Fig. 2. A reduction in insulin dose in the in two competitions. Shaded column represents the proportion of short-acting insulin, and open column intermediate-acting insulin. In the second year, the total reduction was $38 \%$ with a shift to a lesser reduction from shortacting and a greater decline in the dose of intermediate-acting insulin. $*^{*} p<0.001$, indicate difference between the total daily insulin doses during normal day and skiing day

(Fig. 1, $p<0.05$ ). The patients protein intake was approximately $15 \mathrm{~g}$. During the race, the patients ate carbohydrate in total $270 \pm 20 \mathrm{~g}$ or $36 \pm 3 \mathrm{~g}$ per h, which was not significantly different from that in the control subjects. Two-thirds of the carbohydrate was ingested during the latter half of the race. In 1987, the patients reduced their pre-race carbohydrate intake to $38 \pm 3 \mathrm{~g}$, which was similar to that in the control subjects. The amount of protein the patients had for breakfast was increased to approximately $30 \mathrm{~g}$. During the competition, the carbohydrate intake was similar as in the previous study (Fig. 1). After the race, the patients ate according to their usual diet and had $110 \pm 8 \mathrm{~g}$ carbohydrate during the late afternoon and evening.

\section{Insulin dose}

The individual insulin doses are given in Table 1. In 1986, five patients used short-acting insulin in their morning dose and they reduced that by $58 \%$ (range $33-100 \%$ ). All seven patients were taking intermediateacting insulin, and they reduced the dose by $28 \%$ (range 8-47\%) (Fig. 2). The total morning insulin dose was $2.4 \pm 0.8 \mathrm{U}$ of short-acting, and $17.7 \pm 2.9 \mathrm{U}$ intermediate-acting insulin.

In 1987, six patients took short plus intermediateacting insulin in the morning, and they reduced the doses by $35 \%$ (range $0-50 \%$ ) and 38\% (range 25-58\%) respectively. The two patients with multiple injections of short-acting insulin were given $50 \%(5 \mathrm{U})$ of their usual morning dose as short-acting and the same amount intermediate-acting insulin before skiing. The total morning dose was $3.5 \pm 0.6 \mathrm{U}$ of short-acting and $13.8 \pm 2.1 \mathrm{U}$ intermediate-acting insulin. No insulin was given during the races. The evening dose after the
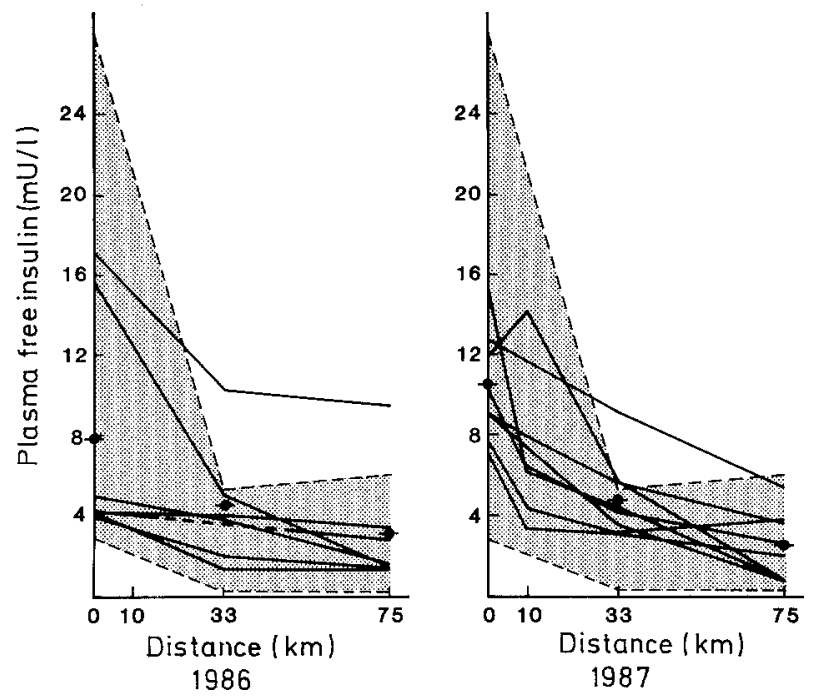

Fig. 3. Plasma free insulin levels in the healthy control subjects (shaded area, mean \pm SD) and diabetic patients (individual and mean values). In the second study, the baseline mean level in the patients was higher than in previous year $(p<0.001)$

race in 1987 was similar as in the resting day in all patients.

The total reduction in insulin dose during 1987 (38\%, range $25-52 \%$ ) was slightly more than during $1986(32 \%$, range $8-48 \%)$. A greater difference was in the distribution of insulin types: in the second year the proportion of short-acting insulin from the total morning dose was $20 \%$, in contrast to only $9 \%$ taken as short-acting insulin in the first year (Fig. 2).

\section{Plasma insulin}

In 1986, the mean plasma free insulin levels in the diabetic patients before the race $(7.8 \pm 2.0 \mathrm{mU} / \mathrm{l})$ were half of that in healthy control subjects $15.6 \pm 3.1 \mathrm{mU} / 1$, $p<0.001$, Fig. 3). During the race, insulin levels fell rapidly in both groups and were no more significantly different. In 1987, the baseline free insulin levels in the diabetic patients were higher than in the previous year (Fig. 3, $p<0.001$ ), but the mean value was still below that in the control subjects $(p<0.001)$.

\section{Blood glucose}

In 1986, the mean pre-exercise blood glucose was $20.3 \pm 1.8 \mathrm{mmol} / \mathrm{l}$. This fell rapidly and was in or below the normal range with the exception of one patient (Fig.4). In 1987, the pre-exercise glycaemia (12.9 $1.6 \mathrm{mmol} / 1)$ was lower than the year before $(p<0.05)$, but still above normal $(p<0.001)$. During the first $10 \mathrm{~km}$ skiing, blood glucose fell with the exception of two patients. In both studies, none of the patients complained of hypoglycaemic symptoms; the lowest blood glucose value recorded at any time during the races was $3.3 \mathrm{mmol} / 1$. 

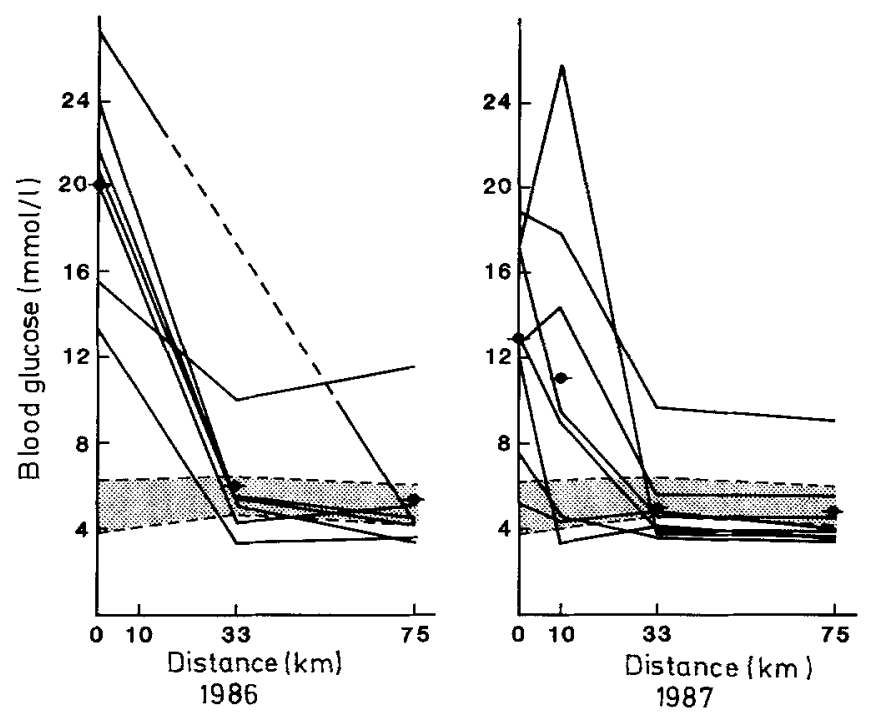

Fig.4. Blood glucose levels in the healthy control subjects (shaded area, mean \pm SD) and diabetic patients (individual and mean values). In the second study, the baseline blood glucose level was significantly lower than in the first study

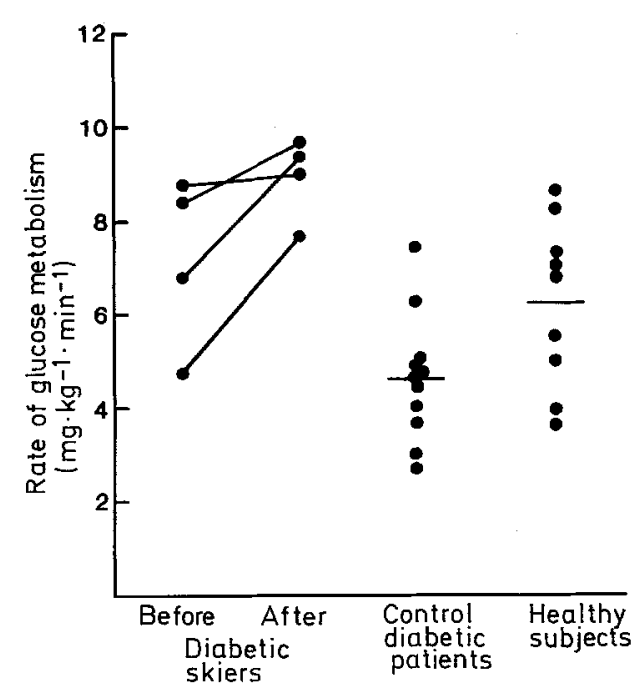

Fig.5. The rate of insulin-mediated glucose metabolism in four diabetic patients measured before and on the day after the endurance exercise. Data for matched sedentary diabetic patients and healthy control subjects are based on previous studies in our laboratory [10]

During the night after the race, the mean blood glucose levels varied between $7.6 \pm 1.1 \mathrm{mmol} / 1$ and $10.5 \pm 1.6 \mathrm{mmol} / 1$ as determined at $4 \mathrm{~h}$ intervals from 20.00 hours on. One out of 7 patients had hypoglycaemic symptoms in the early morning and his blood glucose level was $3.3 \mathrm{mmol} / \mathrm{l}$ (after an extra snack).

\section{Insulin sensitivity}

In the basal state, insulin mediated glucose metabolism in the four patients studied was in the high normal range and above the majority of values of matched diabetic patients not involved in active training (Fig. 5). In the morning after the long-term skiing, insulin mediated glucose metabolism was further improved in each patient.

\section{Discussion}

Although the metabolic response to long-term exercise has been examined in healthy man [11], there is a paucity of data on insulin treated diabetic patients. In normal man, insulin secretion is reduced during exercise, thus allowing an increase in hepatic glucose production to meet the demands of the exercising muscle [11]. Long-term strenuous exercise may lead to hypoglycaemia even in healthy man, if performed without any caloric intake during the race [12]. In diabetic patients, the autoregulation of insulin delivery is missing, and exercise may even stimulate the insulin absorption rate from the injection site [13]. If the insulin dose is reduced too much to avoid hypoglycaemia, this may lead to insulin deficiency, and consequently to excessive hepatic glucose production and lipid mobilisation causing hyperglycaemia and -ketonaemia during exercise [14]. To avoid both hypo- and hyperglycaemia during prolonged exercise, an appropriate adjustment of both insulin dose and diet is important for the patient. How well patients succeed in this long-term competitive exercise is known only in anecdotal cases.

The exercise of the present study was extremely long and strenuous. The rise in serum creatinine and the fall in testosterone levels were similar or greater than those seen during the marathon race $[15,16]$, and the fall in testosterone clearly exceeded the normal diurnal variation. All the patients finished the race, and the skiing time was similar to that in healthy control subjects. Thus diabetes as such does not impair the physical performance even if an exceptionally high capacity is required.

The aim of four first study was to examine how large glycaemic excursions the patients may have, when they adjust the therapy according to the general instructions given for the exercise. To avoid hypoglycaemia during exercise, the patients ingested extra carbohydrate before the race, and reduced the dose of short acting-insulin relatively more than the intermediate-acting one. This resulted in a marked hyperglycaemia and a failure to match with high postprandial insulin levels seen in the control subjects. Although the effects of a transient hyperglycaemia on long-term prognosis may be small, a gross elevation of blood glucose leads to glucosuria and fluid loss, and thus may accelerate dehydration during the exercise. During the latter part of the race, the patients' plasma insulin levels were normal and blood glucose declined to low normal range or shlightly below that. In the control subjects, plasma insulin levels fell rapidly in the beginning of the skiing, when the glucose stimulus after 
breakfast vanished, and the inhibitory effect of exercise on insulin secretion prevailed [17].

Based on the experience of the first study, the following year the diabetic patients were given instructions to reduce the extra carbohydrate loading before the race, and to shift the reduction in insulin dose by taking more short-acting and less intermediate-acting insulin than the year before. With this modification, the pre-race hyperglycaemia was less, whereas blood glucose during the race still remained in low normal range or below that in most patients. Thus, while the average 35\% reduction in short-acting insulin was quite appropriate, the mean reduction in intermediateacting insulin should probably have been more than $38 \%$. Our findings confirm "the insulin-like effect of exercise", described by R.D. Lawrence more than 60 years ago [18]. These results can be used as a guideline for the average adjustment of insulin therapy during long-term endurance exercise. The large interindividual variations, however, should be taken into account and the dose tailored individually with the aim to avoid both hypo- or hyperinsulinaemia during the exercise.

In contrast to the other patients in whom blood glucose fell rapidly at the beginning of the race, two patients demonstrated an initial rise in glycaemia (Fig.4). They were the fastest skiers among the group. The initial rise in blood glucose was obviously a consequence of an acceleration of hepatic glucose production beyond the rate of utilisation, as occurs during very intensive exercise in Type 1 diabetic patients [19].

There is anecdotal evidence of hypoglycaemic symptoms even several hours after exercise in insulin treated patients. The post-exercise hypoglycaemia may be related to ongoing enhanced glucose disposal after exercise. Immediately following acute exercise, glucose tolerance in Type 1 diabetic patients is improved [20], due to augmented glucose transport into muscle cells [21]. The glucose serves to replete glycogen stores, which are depleted particularly after strenuous, longterm exercise [22]. In patients with Type 2 (non-insulindependent) diabetes, increased insulin stimulated glucose disposal has been demonstrated $12-14 \mathrm{~h}$ after a single bout of glycogen-depleting exercise [23]. Increased glucose disposal was through non-oxidative pathways, probably representing glycogen synthesis. To examine whether enhanced glucose disposal is demonstrable in Type 1 diabetic patients on the day after prolonged exercise, we measured insulin mediated glucose uptake directly using the insulin clamp technique. Due to the laborious technique, it was possible to examine only two subjects in each study. In the basal state, the rate of glucose metabolism was in the high normal range and above the values of a majority of sedentary diabetic patients. This is in keeping with enhanced insulin sensitivity induced by training [24, 25]. In all four patients examined, insulin mediated glucose disposal was increased on the day after the race. The magnitude of the improvement varied between the patients. This may reflect variable depletion of glycogen stores during exercise, since the post-exercise feeding was similar in all patients. One of these patients had symptomatic hypoglycaemia during the night after the exercise. Thus, enhanced glucose disposal may exist several hours after heavy exercise and explain the risk for post-exercise hypoglycaemia.

Taken together, our findings indicate that insulin treated diabetic patients can well perform strenuous exercise with a duration of several hours: The appropriate therapeutic adjustment is on the average $35 \mathrm{~g}$ protein and $40 \mathrm{~g}$ carbohydrate before exercise, and $40 \mathrm{~g}$ carbohydrate during each hour of the exercise. Total insulin dose should be reduced on the average by $40 \%$, with a $35 \%$ reduction in morning short-acting and $40 \%$ or more in intermediate-acting insulin. The exact insulin regimen should be tailored individually. The rate of glucose disposal is augmented for several hours following strenuous exercise. This may explain the development of hypoglycaemia after exercise, as experienced by some patients.

Acknowledgements. The skilful technical assistance of Ms. A. Salo and Ms. T.Kerman is appreciated. The study was supported by the Finnish Ministry of Education, the Finnish Academy of Science, and Novo Industry A/S.

\section{References}

1. Koivisto VA (1986) The physiology of marathon running. Sci Prog Oxf 70: 109-127

2. Vranic M, Berger M (1979) Exercise in diabetes mellitus. Diabetes $28: 147-167$

3. Zinman B, Vranic M (1985) Diabetes and exercise. Med Clin North Am 69: 145-156

4. Kadish AH, Litle RL, Stennberg JC (1968) A new rapid method for the determination of glucose by measurement of rate of oxygen consumption Clin Chem 14: 116-121

5. Kuzya H, Blix PM, Horwitz DL, Steiner DF, Rubenstein AH (1977) Determination of free and total insulin and C-peptide in insulin-treated diabetics. Diabetes 26: 22-26

6. Scandinavian Committee on Enzymes (1979) Revised method for determination of creatine kinase in blood. Scand J Clin Lab Invest $39: 7$

7. Ismail AA, Niswender GD, Midgley AR (1972) Radioimmunoassay of testosterone without chromatography. J Clin Endocrinol Metab 34: 177-184

8. Welch GS, Boucher BJ (1978) A rapid micro-scale method for the measurement of hemoglobin $a_{1}(a+b+c)$. Diabetologia 14: 209-211

9. DeFronzo RA, Tobin JD, Andres R (1979) Glucose clamp technique: a method for quantifying insulin secretion and resistance. Am J Physiol 237: E214-E223

10. Yki-Järvinen $H$, Koivisto VA (1986) Natural course of insulin resistance in type 1 diabetes. N Engl J Med 315: 224-230

11. Wahren J, Felig P, Ahlborg G, Jorfeldt L (1971) Glucose metabolism during leg exercise in man. J Clin Invest 50: 2715-2725

12. Felig P, Cherif A, Minagawa A, Wahren J (1982) Hypoglycemia during prolonged exercise in normal men. $\mathrm{N}$ Engl $J$ Med 306: $895-900$

13. Koivisto VA, Felig P (1978) Effects of leg exercise on insulin absorption in diabetic patients. N Engl J Med 298: 79-83 
14. Berger $M$, Berchtold $P$, Cuppers $H J$, rost $H$, Kley HK, Mullen WA, Wiegelmann W, Zimmermann-Telschow $\mathbf{H}$, Gries FA, Kruskemper HL, Zimmerman H (1977) Metabolic and hormonal effects of muscular exercise in juvenile type diabetics. Diabetologia $13: 355-365$

15. Noakes TD, Carter JW (1982) The response of plasma biochemical parameters to a $56-\mathrm{km}$ race in novice and experienced ultramarathon runners. Eur J Appl Physiol 49: 179-186

16. Kuusi T, Kostiainen E, Vartiainen E, Pitkänen L, Enholm C, Korhonen HJ, Nissinen A, Puska P (1984) Acute effects of marathon running on levels of serum lipoproteins and androgenic hormones in healthy males. Metabolism 33: 527-531

17. Pruett EDR (1970) Plasma insulin concentrations during prolonged work at near maximal oxygen uptake. J Appl Physiol 29: $155-158$

18. Lawrence RD (1926) The effects of exercise on insulin action in diabetes. Br Med J 1: 648-652

19. Mitchell TH, Schiffrin A, Marliss E (1986) Hyperglycemia following intense exercise in type 1 diabetes. Diabetes 35 [Suppl I]: 10 (Abstract)

20. Maehlum S, Pruett EDR (1975) Muscular exercise and metabolism in male juvenile diabetics. II. Glucose tolerance after exercise. Scand J Clin Lab Invest 32: 149-153
21. Richter EA, Garretto LP, Goodman MN, Ruderman NB (1984) Enhanced muscle glucose metabolism after exercise: modulation by local factors. Am J Physiol 246: E476-E482

22. Karlsson J, Saltin B (1971) Diet, muscle glycogen and endurance performance. J Appl Physiol 31: 203-206

23. Devlin JT, Hirshman M, Horton ED, Horton ES (1987) Enhanced peripheral and splanchnic insulin sensitivity in NIDDM men after single bout of exercise. Diabetes 36: 434-439

24. Yki-Järvinen H, DeFronzo RA, Koivisto VA (1984) Normalization of insulin sensitivity in type 1 diabetic subjects by physical training during insulin pump therapy. Diabetes Care 7:520-527

25. Koivisto VA, Yki-Järvinen H, DeFronzo RA (1986) Physical training and insulin sensitivity. Diabetes Metab Rev 1: 445-481

Received: 15 June 1987

and in revised form: 29 October 1987

Dr. Timo Sane

III Department of Medicine

Helsinki University Hospital

Haartmaninkatu 4

SF-00290 Helsinki

Finland 